THE PHOTOGRAPH A Strange Confined Space

s. 



\section{THE PHOTOGRAPH}

A Strange Confined Space

Mary Price

STANFORD UNIVERSITY PRESS, STANFORD, CALIFORNIA 


\section{Stanford University Press}

Stanford, California

(C) 1994 by the Board of Trustees of the

Leland Stanford Junior University

CIP data appear at the end of the book

Stanford University Press publications

are distributed exclusively by Stanford University Press within the United States, Canada, Mexico, and Central America; they are distributed exclusively by Cambridge

University Press throughout the rest of the world.

Original printing I 994

Last figure below indicates year of this printing:

$\begin{array}{llllllllll}04 & 03 & 02 & \text { OI } & 00 & 99 & 98 & 97 & 96 & 95\end{array}$ 
To Martin 



\section{Acknowledgments}

My most enduring debt is to Martin Price, whose sharpness as critic was never blunted by deference to any other role. I profited greatly from his early readings. The Center for Independent Study, a resource for writers, scholars, artists, and translators who are not connected with an institution, has offered steady encouragement. The following past or present members have been directly or indirectly helpful: Roger Baldwin, William Burney, Ellen Chirelstein, Phyllis Crowley, Marlene Demarque, Lila Freedman, Liliane Greene, Ruth Hein, Shelagh Hunter, Eve Ingalls, and Leslie Jackson.

Ellen Graham, June and Jacques Guicharnaud, John Hollander, Joseph Reed, and Patricia Meyer Spacks read all or part of some earlier draft. The criticism of each was generous and acute.

Tom Hricko taught me the procedures of photographing. Alan Trachtenberg has been supportive of my interest in photography for a long time.

Thomas Victor, a New York photographer, some years ago taught a seminar on photography in Silliman College, of which I was then a Fellow. Some of the questions the class raised for me are those I have attempted to deal with here. I owe Tom and the class members thanks.

I must also add general thanks to Paul Pickrel, my predecessor at The Yale Review, and to John Palmer, former editor. And among those who set standards, Margaret and Bill Wimsatt.

Trudie Calvert was the able and meticulous copyeditor. Helen Tartar, Humanities Editor at the Stanford University Press, was indeed a humane 
editor. John Feneron helped transform the manuscript into a book. I am grateful to everyone connected with the Press for their attention to detail and their interest in the book.

The responsibility for the book, however, belongs to me, O Lord, to me, and to none of the above.

M.P. 